\title{
Smíšený design ve výzkumu recepce poezie ${ }^{1}$
}

\section{Mixed methods design in the research of the reception of poetry}

\author{
Jaroslav Vala
}

\begin{abstract}
Abstrakt: Studie představuje letos zahájený tř́letý výzkumný projekt (GAČR), zaměřený na zkoumání recepce poezie a na možnosti jejího ovlivňování. Objasníme cíle, design a jednotlivé fáze výzkumu. Přitom se zaměříme na první průběžné výsledky longitudinální části projektu, které vycházejí z reflexí participujících učitelů i žáků. Kvantitativní metody sběru dat vytvářejí základní rámec a jsou doplněny metodami kvalitativními. V rámci první linie výzkumu používáme sémantický diferenciál a Q-metodologii. Hlavní součást druhé linie představuje longitudinální šetření v osmi školních třídách, kterým chceme zjistit, jak je možné vhodnou metodikou založenou zejména na recepční estetice a zážitkové pedagogice budovat vztah studentů k umělecké literatuře, konkrétně poezii. Po dobu experimentu si studenti formou „deníkových záznamů“ $\mathrm{z}$ iniciativy učitele zaznamenávají své čtenářské postoje a prožitky, podobně si své postřehy zaznamenávají učitelé. Po jeho skončení budeme sledovat posuny v postojích vůči poezii, literatuře a metodám výuky.
\end{abstract}

Klíčová slova: recepce poezie; didaktika literatury; longitudinální výzkum; sémantický diferenciál; Q-metodologie; učitelské a studentské reflexe výuky

\begin{abstract}
This study introduces a three-year research project (GA CR) which started this year. It is aimed at the research of the reception of poetry and possible ways how to influence it. It provides the explanation of the goal, design and separate stages of the project. The first and current results of the longitudinal part of the project are presented which are based on both the participating teachers' and students' reflection. The basis is formed by quantitative methods of data collection which are supplemented by qualitative methods. The first line of the project is based on semantic differential and Q-methodology. The main part of the second line consists of longitudinal research in eight school classes, the aim of which is to find out about the possibilities of developing students' interest in fiction and particularly poetry with the use of suitable methodology based especially on the reception aesthetics and experience pedagogics. In the course of the experiment, students are encouraged by the teacher to record their reading attitudes and experiences in the form of a "diary" and the teachers record their observations as well. After finishing this experiment we are going to observe the shift in the attitudes towards poetry, literature and educational methods.
\end{abstract}

Keywords: reception of poetry, literature didactics, longitudinal research, semantic differential, Q-methodology, teachers' and students' reflection on teaching

\footnotetext{
1 Článek vznikl za finanční podpory Grantové agentury České republiky (GAČR) - projekt P407/11/0594 s názvem Výzkum recepce poezie u pubescentních a adolescenčních čtenářů (2011-2013).
} 


\section{1 Úvod}

V literární výchově na základní škole se dlouhodobě vede spor o podíl faktografického a zážitkového přístupu $\mathrm{k}$ výuce a př́stup pedagogů i v rámci jedné školy bývá diametrálně odlišný. Šlapal (Koštálová et al., 2010) charakterizuje výstižně dva možné přístupy k literární výchově:

- Osleplá cesta - čtení z čítanky, plnění následných úkolů a literární nauka.

- Možné cesty - dílna čtení, čtenářské strategie založené na metodách rozvoje čtenářské gramotnosti, tvořivé výstupy apod.

První cesta přestává fungovat: žáci čtou často texty, jejichž smysl nechápou a s nimiž se míjejí. Texty určené pro doplnění literární nauky bývají př́iliš náročné a často slouží především jako zdroj k vyhledávání odpovědí. Konkrétní situaci na základních školách se věnovalo několik výzkumů, které byly založeny na výpovědích žáků (Vala, 2003; Hník, 2010). Z nich vyplývá, že kurikulum je předimenzované, práce s literárním textem se v praxi redukovala na rozbor literárněhistorický, popř. na pouhé převyprávění přečteného. Chybí prostor pro reflexi, vzájemnou diskusi žáků a vyjasňování si postojů. Zvláště obtížnou pozici má v této souvislosti poezie, které se učitelé mnohdy obávají a ve výuce vyhýbají. Podobný postoj pak mohou přenášet na své žáky, kteří považují pak poezii za nepř́istupnou oblast literatury určenou pouze úzkému okruhu zájemců (Benton, 1999; Benton, 2000).

Studie je představuje letos zahájený tř́letý výzkumný projekt Grantové agentury ČR zaměřený na zkoumání recepce poezie u žákủ základních a středních škol a na možnosti jejího ovlivňování metodami výuky. Objasníme cíle, design a jednotlivé fáze výzkumu. Přitom se zaměříme na průběh longitudinální části projektu a první průběžné výsledky, které vycházejí z reflexí participujících učitelů.

\section{Cíle projektu}

V základní rovině je cílem projektu prohloubení poznání recepčního procesu u pubescentních a adolescentních čtenářu (věková kategorie 12-19 let). Usilujeme o obohacení spektra výzkumných metod uplatnitelných ve výzkumech vnímání umělecké literatury a zejména poezie. Záměrem projektu je získat komplexnější představu o recepčním procesu a zároveň o možnostech, jak jeho kvalitu pozitivně ovlivňovat. Pohybujeme se na pomezí pedagogiky, psychologie a literární vědy a hledáme souvislosti mezi osobnostními charakteristikami respondentů a jejich čtenářskými preferencemi.

Konkrétní formulace cílů:

- Analýza čtenářského vnímání básnického textu u studentio základních a středních škol.

- Komparace výsledků čtenářských preferencí různých typů poezie a mezi různými kategoriemi respondentů: podle věku, pohlaví, studijního zaměření, prospěchu, vztahu k četbě, vlastní literární tvorby apod.

- Vytvoření souboru efektivnich vyučovacích postupio a metod vycházejících ze zážitkové pedagogiky, praktické estetiky a respektujících principy recepční estetiky.

- Deskripce vývoje a proměn ve vztahu k literatuře (longitudinální výzkum) u studentů osmi tř́d (ZŠ a SŠ), ve kterých budou využívány výše uvedené metody. Používáme techniku paralelních skupin, výsledky experimentální skupiny srovnáváme se skupinou kontrolní ve stejném typu školy.

- Analýza výsledků všech provedených výzkumných měrení a formulace základních vývojových tendencí v recepci poezie v závislosti na kategoriích respondentů. 


\section{Design výzkumného projektu}

$\mathrm{Na}$ základě aktuálních poznatků v oblasti pedagogického výzkumu usilujeme o průnik do recepčního procesu kvantitativními výzkumnými metodami a o zachycení měřitelné části čtenářských prožitků recipientů - pubescentních i adolescentních čtenářru. Kvantitativní metody sběru dat vytvářejí základní rámec a pro komplexnost analýzy jsme je doplnili metodami kvalitativními, abychom získali celistvější představu o různých aspektech studentského vnímání poezie.

$\mathrm{V}$ rámci první linie výzkumu používáme dvě metody: sémantický diferenciál a Qmetodologii. Vlastní recepci básnických textů sledujeme metodou sémantického diferenciálu a zaměřujeme se na preferenci různých typů poezie $u$ různých kategorií respondentů. Postupnou úpravou a doplňováním výzkumných škál standardní verze tohoto výzkumného nástroje a jejich testováním jsme v předchozích výzkumech pomocí faktorové analýzy izolovali tř́i nezávislé faktory: faktor srozumitelnosti, faktor hodnocení a faktor působivosti. Extrakce faktorů byla provedena pomocí metody hlavních komponent a bylo použito rotované řešení (varimax normalizovaný). Vzájemnou nezávislost tř́i sledovaných faktorů jsme ověřili korelační R-maticí. Reliabilita provedených měření byla ověřena metodou půlení (split-half method) a Cronbachovým koeficientem alfa. U jednotlivých básní se interval udržoval ve vysokých hodnotách: např. Cronbachův koeficient alfa pro srozumitelnost 0,859-0,933, hodnocení 0,859-0,951 a pưsobivost 0,813-0,889 (Vala, 2010).

Druhou použitou metodou, která má zpřesnit a doplnit informace získané sémantickým diferenciálem, je Q-metodologie. $Q$-typy v projektu obsahují širokou škálu výpovědí o čtenářství, názorech a postojích k četbě, o životních hodnotách, aktuálním naladění a především o konkrétních básních.

$\mathrm{V}$ rámci druhé linie projektu, založené na kvalitativním př́stupu, používáme metody rozhovoru, dotazníku a ohniskových skupin (Morgan, 2001). Hlavní součástí této linie je dvouleté longitudinální šetření v osmi školních třídách (na ZŠ i SŠ), kterým chceme zjistit, jak je možné vhodnou metodikou založenou zejména na recepční estetice a zážitkové pedagogice budovat vztah studentů $\mathrm{k}$ umělecké literatuře, konkrétně poezii. Vyučovací hodiny koncipujeme tak, aby u studentů docházelo ke změně stereotypního pohledu na poezii a k formování pozitivního vztahu - jejich součástí jsou i studentské diskuse nad literárními texty a možnostmi jejich významů. Studenti si průběžně z iniciativy učitele formou deníkových záznamů zaznamenávají své čtenářské postoje, prožitky a vztah k jednotlivých vyučovacím metodám a aktivitám.

V úvodu projektu vyplnili studenti dotazník sledující jejich vztah k literatuře, literární výchově, vyučovacím metodám apod. Stejný dotazník vyplní i při ukončení této fáze projektu a budeme sledovat př́ípadné posuny jejich pohledu na zmíněné oblasti. Stejný dotazník vyplnili i studenti kontrolních tř́́d, kde výuka postupuje standardním způsobem.

\section{Longitudinální výzkum - hlavní principy a reflexe učitelů}

Učitelé zapojení do longitudinálního projektu obdrželi dvacet námětů na vyučovací hodinu, z nichž si mohou vybírat podle svého uvážení, které vyzkoušejí ve své tř́ídě. Kromě těchto námětů dostali podrobně popsaných pět aktivit, které by měly být realizovány (některé i opakovaně) do konce kalendářního roku 2011 ve všech experimentálních trrídách: 
1. Co je báseň - výzkum zjištující u žáků jejich vnitřní definici poezie.

2. Doplňování chybějících slov (popř. veršů) do básnických textů.

3. Psaní poezie.

4. Opakované navracení se k náročnějšímu textu.

5. Převádění básní do prózy a zpět.

Úvodní dvě aktivity vedou žáky k hlubšímu zamyšlení nad smyslem a podstatou poezie a připravují půdu pro vlastní studentskou básnickou tvorbu. Psaní poezie ve školách umožňuje především sebevyjádření žáků a konkrétnější formulování vnitřních pocitů a emocí. Napomáhá tak sebepoznání. Při citlivém vedení ze strany pedagoga žáci poezii mohou vnímat jako prostor pro vyjádření emocí a citů. Navíc oceňují, že při této činnosti mají výrazně volnější a důvěrnější kontakt s učitelem, než je tomu při četbě poezie, nebot' učitel respektuje svobodu, kterou při psaní poezie mají. Dalším pozitivem psaní poezie je, že schopnost projevit se mají i ti žáci, kteří patří k prospěchově slabším, protože psaní básní jim umožňuje zacházet se slovy volně, bez nutnosti podřizovat se zaběhaným jazykovým stereotypům. Poznávají možnosti jazyka a získávají sebevědomí v zacházení s psanými slovy. Vlastním psaním v sobě žáci zároveň probouzejí porozumění pro již napsané.

Předpokládáme, že všechny výše uvedené aktivity přispějí k tomu, že studenti v experimentálních třídách budou vykazovat výraznější kladný posun ve vnímání umělecké literatury i poezie. $\mathrm{Na}$ hodnocení výsledků je př́liš brzy, přesto lze z reflexí učitelů zapojených do projektu zjistit, že mnozí žáci jsou schopni a ochotni se pro poezii i nadchnout. Pro ilustraci uvádíme komentář učitelky k žákovskému psaní poezie, při kterém vychází ze žákovských deníků:

Pocity po zadání úkolu:

- $\quad u$ většiny dětí je v denících možno pozorovat nejistotu, která je vyvolaná především tím, že úkol není dobrovolný;

- některé děti piší, že si vỉbec nedovedou predstavit, že napíši báseň, naopak některé se těší, píší, že už s tím zkušenost mají a že se těší;

Pocity po vytvoření vlastní básně:

- většina dětí hodnotí tuto aktivitu velmi kladně, některé jsou nadšené a chtějí si to zopakovat;

- některé děti príiznávají, že jim tato práce dala zabrat, jiné naopak píší, že báseñ napsaly velmi rychle a že jich napsaly více.

Pocity po hodnocení básní:

- ve většině deníkových záznamů žáci uvádějí, že nečekali, že někteří spolužáci, u kterých by to vi̊bec nepredpokládali, jsou schopni napsat básničku;

- celkově je tato práce hodnocena velice kladně;

- je opravdu vidèt jakýsi posun k lepšímu v nahližení dètí na poezii. 


\section{Závěr}

Představený výzkumný projekt zaměřený na recepci poezie je teprve ve své úvodní části a probíhá především sběr dat. Průběžné výsledky longitudinální části výzkumu přesto přinášejí první zajímavé informace a důležité je, že studenty výuka baví a poezie se nutně nemusí bát. A baví i učitele. Sice jim zapojení do projektu přináší množství práce navíc, ale vnímají to jako profesní obohacení. Získané výsledky mohou na základě srovnání efektivity různých vyučovacích metod přispět mj. k rozvoji didaktiky literární výchovy, přinést zefektivnění přímo do vyučovacího procesu a podílet se na rozvoji čtenářské gramotnosti žáků.

\section{Literatura}

Benton, P. (1999). Unweaving the rainbow: poetry teaching in the secondary school I. Oxford Review of Education, 25(4), 521-532.

Benton, P. (2000). The conveyor belt curriculum? Poetry teaching in the socondary school II. Oxford Review of Education, 26(1), 81-93.

Hník, O. (2010). Současná podoba výuky literární výchovy podle výpovědí studentů. Český jazyk a literatura, 61(1), 33-39.

Košt’álová, H. a kol. (2010). Čtenářská gramotnost jako vzdělávací cíl pro každého žáka. Praha: Česká školní inspekce.

Morgan, D. L. (2001). Ohniskové skupiny jako metoda kvalitativního výzkumu. Brno: Psychologický ústav Akademie věd.

Vala, J. (2010). Poezie z pohledu adolescenčních čtenářn. Česká literatura, 58(3), 346-369.

Vala, J. (2003). Literatura na základní škole očima žáků. In M. Mlčoch (Ed.), Tradiční a netradiční metody a formy práce ve výuce českého jazyka na základní škole (pp. 53-57). Olomouc: UP v Olomouci.

\section{Kontakt}

Mgr. Jaroslav Vala, Ph.D.

Univerzita Palackého

Pedagogická fakulta, Katedra českého jazyka a literatury

Žižkovo nám. 5, 77140 Olomouc

e-mail: jaroslav.vala@upol.cz

\section{Bibliografické údaje}

Vala, J. (2011). Smíšený design ve výzkumu recepce poezie. In T. Janík, P. Knecht, \& S. Šebestová (Eds.), Smišsený design v pedagogickém výzkumu: Sborník př́spěvků z 19. výroční konference České asociace pedagogického výzkumu (s. 446-450). Brno: Masarykova univerzita.

Dostupné z: http://www.ped.muni.cz/capv2011/sbornikprispevku/vala.pdf

doi: 10.5817/PdF.P210-CAPV-2012-81 